\title{
ANALISIS DAYA SAING EKSPOR KOPI INDONESIA DI PASAR INTERNASIONAL
}

\author{
Felicitas Parnadi \\ Program Studi Magister Manajemen Universitas Tarumanagara \\ gf.parnadi@gmail.com \\ Riris Loisa \\ Program Studi Magister Manajemen Universitas Tarumanagara
}

\begin{abstract}
This study aims to analyze and know how the level of competitiveness of Indonesian coffee exports in the International Market. The study was conducted using secondary data from various sources, including from BPS (BPS, 2016), Indonesian Ministry of Agriculture, International Coffee Organization, 2016) and AEKI (2016). Secondary data used in the form of time series data in the period of 7 years (2010-2016). Coffee is the object of research is all types of coffee. The data analysis method uses quantitative analysis method which is used to analyze the level of competitiveness of Indonesian coffee commodity exports in international market which include: Revealed Comparative Advantage (RCA), Import Dependency Ratio (IDR), and Index of Market Specialization (ISP). Data processing will be done using Microsoft Excel 2013 software.Based on the analysis of Revealed Comparative Advantage (RCA) value, from 2010-2016 of 3.57, Indonesia has a comparative advantage in the coffee trade in the international market. However, the comparative advantage of Indonesia is still low compared to Colombia, Vietnam and Brazil, although still higher than India. The level of dependence on Indonesian coffee imports is calculated by using Import Dependency Ratio (IDR) of 1.42 percent. Indonesian coffee has a high competitiveness, as the value of the Indonesian Trade Specialty Index (ISP) of 0.91. This indicates that Indonesia is an exporting country for coffee commodities. Positive ISP results greater than 0 indicate that Indonesia's coffee commodity has a strong competitiveness, because the value of Indonesian coffee exports is greater than the value of Indonesian coffee imports.
\end{abstract}

Keywords: Comparative Advantage, Export, Import, Revealed Comparative Advantage (RCA), Import Dependency Ratio (IDR), Indeks Spesialisasi Perdagangan (ISP)

\section{LATAR BELAKANG}

Indonesia adalah salah satu negara produsen dan eksportir kopi paling besar di dunia. Berkaitan dengan komoditi-komoditi agrikultur, kopi adalah penghasil devisa terbesar keempat untuk Indonesia setelah minyak sawit, karet dan kakao. Dengan keunikan cita rasa dan aroma kopi asal Indonesia, Indonesia memiliki peluang besar untuk meningkatkan perdagangan kopinya di dunia.

Indonesia pernah mencapai puncaknya sebagai negara penghasil kopi terbesar ketiga di dunia setelah Brasil dan Vietnam pada tahun 2012-2013, Indonesia mampu memproduksi sedikitnya 748 ribu ton atau 6,6\% dari produksi kopi dunia pada tahun 2012. Dari jumlah tersebut, produksi kopi robusta mencapai lebih dari 601 ribu ton atau sebesar 80,4\% dan produksi kopi arabika mencapai lebih dari 147 ribu ton atau sejumlah 19,6\%. Pada saat itu, dari total produksi kopi Indonesia, sekitar 67\% kopi diekspor, sedangkan sisanya 33\% untuk memenuhi kebutuhan dalam negeri (Kementrian Perdagangan, 2014). Berdasarkan data Badan Pusat Statistik (BPS), impor kopi Indonesia pada Januari-Februari 2017 tercatat 
sebesar 1.259 ton dengan nilai US\$ 4,73 juta. Impor kopi paling besar datang dari Brasil dengan volume sebanyak 806 ton dengan nilai US\$2,86 juta, kemudian disusul Vietnam sebanyak 247 ton dengan nilai US\$ 585 ribu. Sisanya didatangkan dari Malaysia, Timor Leste, dan Amerika Serikat (Idris, 2017).

Berdasarkan data Badan Pusat Statistik (BPS), impor kopi Indonesia pada JanuariFebruari 2017 tercatat sebesar 1.259 ton dengan nilai US\$ 4,73 juta. Impor kopi paling besar datang dari Brasil dengan volume sebanyak 806 ton dengan nilai US\$ 2,86 juta, kemudian disusul Vietnam sebanyak 247 ton dengan nilai US\$ 585 ribu. Sisanya didatangkan dari Malaysia, Timor Leste, dan Amerika Serikat (Idris, 2017). Walaupun Indonesia merupakan salah satu negara produsen komoditas kopi terbesar di dunia namun pada kenyataannya laju pertumbuhan nilai dan volume impornya lebih besar ketimbang ekspor. Tingginya impor ini karena potensi pertumbuhan produksi kopi tidak diikuti dengan kapasitas perbaikan produksi dan regulasi yang mampu mendorong ekspornya (Sudoyo, 2013).

Tujuan ekspor kopi Indonesia masih didominasi oleh negara-negara Eropa, USA, dan beberapa negara Asia seperti Jepang, Malaysia, Korea Selatan, Taiwan, Filipina, Singapura dan beberapa negara Afrika seperti Afrika Selatan, Mesir dan UEA. Amerika Serikat merupakan negara pengimpor produk kopi terbesar pertama di Indonesia. Permintaan ekspor produk kopi Indonesia ke pasar Amerika Serikat (AS) terbilang paling tinggi dibandingkan ke negara-negara lain (BPS, 2016).

Semakin meningkatnya permintaan jumlah ekspor kopi Indonesia ke pasar luar negeri menunjukkan bukti keberhasilan produk kopi Indonesia dalam menembus pasar internasional dan mampu bersaing dengan produk kopi dari negara-negara lain sehingga mampu mempengaruhi tingkat pertumbuhan perekonomian Indonesia serta pula mampu meningkatkan taraf kesejahteraan penghasilan bagi para petani kopi.

Perkembangan perdagangan kopi dunia saat ini juga terus mengalami pertumbuhan. Hal ini tercermin pada nilai volume ekspor kopi di setiap negara eksportir kopi dunia yang mana setiap tahunnya terus meningkat, membawa persaingan komoditas kopi Indonesia menjadi Top 5 eksportir kopi dunia yang berada pada urutan keempat pada sisi kuantitas maupun dari segi value ekspornya.

Permasalahan lain yang muncul saat ini adalah pasar kopi olahan lebih banyak dikuasai Brasil, Kolombia, Ekuador, India dan Pantai Gading, sehingga praktis Indonesia untuk kopi olahan volume ekspornya masih kecil sekali dan hanya dapat mengandalkan dari pasar dalam negerinya sendiri. Daya saing ekspor suatu komoditas adalah kemampuan suatu komoditas untuk memasuki pasar luar negeri yang kemudian memiliki kemampuan untuk mempertahankan pasar tersebut. Daya saing suatu komoditas dapat diukur atas perbandingan pangsa pasar (market share) komoditi tersebut pada kondisi pasar yang tetap.

Melihat data hasil produksi kopi Indonesia dalam kurun waktu 2010-2016 dapat dikatakan sangat fluktuatif, namun komoditas kopi Indonesia masih mampu memberikan kontribusi besar sebagai salah satu penopang devisa terbesar untuk sektor non-migas, khususnya pada sektor hasil perkebunan. Hal ini dikarenakan sebagian besar hasil produksi kopi Indonesia yaitu sebesar $61.5 \%$ menjadi komoditas ekspor kopi dunia. Pada tahun 20122013, Indonesia pernah menjadi negara penghasil kopi terbesar ketiga di dunia setelah Brasil dan Vietnam. Indonesia mampu memproduksi sedikitnya 748 ribu ton atau $6,6 \%$ dari produksi kopi dunia pada tahun 2012. Dari jumlah tersebut, produksi kopi robusta mencapai lebih dari 601 ribu ton atau sebesar 80,4\% dan produksi kopi arabika mencapai lebih dari 147 ribu ton atau sejumlah 19,6\%. Pada saat itu, dari total produksi kopi Indonesia, sekitar $67 \%$ kopi diekspor, sedangkan sisanya $33 \%$ untuk memenuhi kebutuhan dalam negeri (Kementrian Perdagangan, 2014). 
Adanya negara pesaing terbesar Indonesia seperti Brazil, Colombia, Vietnam dan India mendorong industri perkopian Indonesia untuk meningkatkan kualitas kopi serta kemampuan untuk bersaing di pasar Internaional. Persaingan dengan Negara-negara produsen utama kopi mengakibatkan pengembangan ekspor kopi Indonesia dalam jangka panjang sangat ditentukan oleh peningkatan kualitas komoditas dan kemampuan dayasaingnya. Oleh karena itu, hal yang sangat penting dilakukan saat ini adalah menganalisis daya saing dari komoditas kopi Indonesia sehingga peranannya dalam perekonomian dapat diandalkan.

Permasalahan perdagangan kopi di dunia saat ini adalah bagaimana kemampuan daya saing produk kopi kita dalam bersaing di pasaran kopi internasional karena pada sisi produktivitas, volume, kualitas mutu serta value dari sisi ekspor kopi Indonesia belum unggul. Dengan adanya latar belakang ini maka penulis mengambil judul "Analisis Daya Saing Ekspor Komoditas Kopi Indonesia di Pasar Internasional". Adapun rumusan masalah yang hendak diajukan adalah: Bagaimana tingkat daya saing ekspor kopi Indonesia di Pasar Internasional?.

\section{TELAAH KEPUSTAKAAN}

\section{Teori dan Hukum Permintaan Penawaran}

Setiap transaksi perdagangan dalam suatu kegiatan ekonomi, pastilah terdapat permintaan (demand), penawaran (supply), harga dan kuantitas akan suatu barang atau jasa yang saling mempengaruhi satu dengan yang lainnya. Permintaan dan penawaran akan saling bertemu dan akan membentuk satu titik pertemuan dalam satuan harga dan kuantitas (jumlah barang). Permintaan dan penawaran dalam ilmu ekonomi merupakan suatu penggambaran atas hubungan-hubungan di pasar, antara para calon pembeli dan penjual terhadap suatu barang/jasa.

\section{Pengertian Permintaan}

Pengertian permintaan secara umum dalam ilmu ekonomi diartikan sebagai keinginan seseorang (konsumen) terhadap barang-barang tertentu yang diperlukan atau diinginkan (Sukirno, 2008:13). Permintaan mencerminkan perilaku konsumen dalam membeli barang atau jasa tertentu. Sedangkan penawaran mencerminkan perilaku produsen dalam menjual barang atau jasa tertentu. Permintaan dan penawaran bersama-sama akan membentuk pasar (Prasetyo, 2011:24).

Terdapat beberapa macam unsur komponen dasar dalam suatu aktifitas ekonomi yang berhubungan dengan permintaan di pasar. Macam-macam unsur komponen permintaan tersebut adalah: (Case dan Fair, 2007:86); (1) Harga permintaan, (2) Pendapatan dari permintaan, (3) Elatisitas dari permintaan, (4). Banyak faktor mempengaruhi permintaan pasar untuk suatu produk selain harga itu sendiri. Faktor-faktor tersebut antara lain: (1) Perilaku Konsumen, (2) Intensitas kebutuhan konsumen, (3) Selera konsumen, (4) Pendapatan dan kekayaan konsumen, (5) Persediaan dan harga barang sejenis, (6) Harga barang pelengkap, (7) Perkiraan harga di masa yang akan datang, (8) Jumlah Konsumen, (9) Corak distribusi, (10) Pajak, (11) Pertambahan penduduk

\section{Pengertian Penawaran}

Dalam ilmu ekonomi, penawaran (supply) diartikan sejumlah barang, produk atau komoditi yang tersedia dalam pasar yang siap untuk dijual kepada konsumen yang membutuhkannya. Penawaran juga dapat diartikan sebagai sejumlah barang (goods), jasa (service) atau komoditi yang tersedia di pasar dengan harga tertentu pada waktu tertentu (Sukirno, 2008:19). Penawaran dipengaruhi berbagai faktor berikut: (Case \& Fair, 2007:113); (1) Biaya Produksi, (2) Harga produk yang berkaitan, (3) Pemakaian teknologi yang digunakan, (4) Tujuan produksi dari suatu perusahaan, (5) Pajak, (6) Ketersediaan dan harga barang pengganti, (7) Perkiraan harga dimasa depan, (8) Harga bahan baku.

\section{Standar Kualitas Kopi}


Kopi Wajib memiliki Standar Mutu sebagai control kualitas cita rasa- Standar mutu sangat penting sebagai bentuk petunjuk pengawasan mutu serta sebagai kontrol kualitas untuk menghadapi klaim/ketidakpuasan dari buyer Standardisasi mencakup klasifikasi, metode pengambilan sampel, syarat mutu, metode uji, metode pengemasan. Syarat mutu umum Biji kopi dengan metode pengolahan kering sesuai Standar Nasional Indonesia No.012907-1999 adalah sebagai berikut; (1) Tidak ada Biji bau busuk dan bau kapang, (2) Tidak mengandung serangga hidup, (3) Kadar air maksimal 13\%, (4) Kadar kotoran maksimal 0,5\%, (5) Biji lolos ayakan ukuran $3 \mathrm{~mm}$ x $3 \mathrm{~mm}$ maksimal 5\%, (6) Biji ukuran besar, lolos ayakan ukuran 5,6 $\mathrm{mm}$ x 5,6 mm maksimal 5\%. Standar mutu kopi ini disusun oleh Departemen Perdagangan untuk memenuhi tuntutan perkembangan pemasaran kopi dengan memperhatikan standar mutu kopi dari berbagai negara penghasil kopi dan konsumen kopi di dunia (Saddakoffie.com, 2018).

\section{Produksi Kopi dan Luas Areal Tanaman kopi}

Produksi kopi Indonesia dari tahun ke tahun terus mengalami penurunan. Tahun 2013, produksi biji kopi Indonesia tercatat 500.000 ton, turun dari 2012 sebesar 600.000 ton, dan di 2011 sebesar 700.000 ton (Finance.detik.com, 2014). Asosiasi Eksportir Kopi Indonesia (AEKI) mencatat, produksi kopi 2016 sebesar 625.000 ton, turun dari produksi tahun 2015 yang sebesar 680.000 ton. Tahun 2017, AEKI memperkirakan, produknya turun 0,27\% menjadi 637.539 ton. Produksi kopi Tanah Air diprediksi terus menurun karena dampak El Nino. Penurunan ini diyakini akan memperlebar kebutuhan kopi yang kini makin meningkat (Elisabeth Adventa, 2017).

Pada saat ini, perkebunan kopi Indonesia mencakup total wilayah kira-kira 1,24 juta hektar, 933 hektar perkebunan robusta dan 307 hektar perkebunan arabika. Lebih dari 90\% dari total perkebunan dibudidayakan oleh para petani skala kecil. Produksi kopi Indonesia sebesar 639.305 ton dengan produktivitas 707 kilogram/ha. Paling banyak dikembangkan di Indonesia jenis kopi robusta sekitar 76,2\% dan arabika 23,8\%. Hampir 96\% merupakan perkebunan milik rakyat, melibatkan tenaga kerja sekitar 1,8 juta kepala keluarga (KK). Dengan rata-rata kepemilikan lahan 0,6 ha (Devito Martha, 2017).

\section{Perdagangan Internasional}

Teori perdagangan internasional, seperti halnya model-model equilibrium umum persaingan sempurna lainnya dalam ilmu ekonomi, bukan hanya merupakan sebuah model dengan asumsi lapangan kerja penuh, tetapi juga dengan asumsi dimana harga-harga produk dan sumber daya domestik maupun internasional selalu menyesuaikan diri secara instan terhadap berbagai perubahan kondisi penawaran dan permintaan. Di beberapa kantong ekonomi (enclave economies) di negara-negara berkembang, seperti wilayah dengan operasi pertambangan dan perkebunan milik asing yang substansial, para warga asing seringkali membayar sewa yang sangat rendah atas hak penggunaan lahan., sembari membawa modal dan tenaga kerja asing mereka, merekrut pekerja lokal tidak terampil dengan upah setingkat subsistem, dan berdampak minimum terhadap perekonomian secara umum sekalipun menghasilkan penerimaan ekspor yang besar.

Dengan berkembang pesatnya perusahaan multinasional serta semakin meningkatnya kepemilikan asing pada perusahaan dalam negeri, statistik agregat atas pendapatan ekspor (GDP) dalam negeri tentunya yang berstatus sebagai negara berkembang bisa menyelubungi kenyataan bahwa penduduk dalam negeri terutama lapisan penduduk yang lebih miskin, tidak diuntungkan dari adanya ekspor tersebut. Keuntungan terbesar mungkin malah mengalir kepada warga negara asing, yang sering kali merepatriasikan sebagian besar pendapatan itu ke negara asalnya (Krugman dan Obstfeld, 1990:54).

\section{Keuntungan dan Dampak Perdagangan Internasional}

Simpulan beberapa manfaat yang dapat diambil dari perdagangan internasional antara lain : (Tambunan, 2004:77); (1) Efisiensi, (2) Perluasan konsumsi dan produksi, (3) Peningkaan produktifitas, (4) Sumber penerimaan Negara. Berdasarkan beberapa keuntungan 
dan manfaat dengan adanya perdagangan internasional di atas, maka dampak positif yang dapat ditimbulkan melalui aktifitas perdagangan internasional adalah: (Hady, 2001:41); (1) Meningkatkan kesejahteraan, (2) Mempercepat pembangunan, (3) Meningkatkan sumber daya manusia, (4) Alih teknologi

Adapun dampak negatif yang muncul akibat perdagangan internasional adalah sebagai berikut: (1) Menimbulkan ketergantungan kepada negara lain, (2) Cenderung statis, (3) Pengusaha yang tidak kompetitif terancam gulung tikar, (4) Adanya perubahan nilai sosial budaya

\section{Pengertian Ekspor dan Impor}

Ekspor adalah sistem perdagangan dengan cara mengeluarkan barang-barang dari dalam negeri ke luar negeri dengan memenuhi ketentuan yang berlaku. Ekspor merupakan total barang dan jasa yang dijual oleh sebuah negara ke negara lain, termasuk diantaranya barang-barang, asuransi, dan jasa-jasa pada suatu tahun tertentu (Utomo, 2000:56). Fungsi penting komponen ekspor dari perdagangan luar negeri adalah negara memperoleh keuntungan sehingga pendapatan nasional (devisa) akan naik, sehingga nantinya dapat menaikkan jumlah output dan laju pertumbuhan ekonomi.

Impor merupakan aliran perdagangan suatu komoditi dari luar negeri ke dalam negeri (Sujuna dan Wiharno, 2003). Impor merupakan kebocoran dan pendapatan, karena akan menimbukan aliran modal ke luar negeri.

\section{Konsep Daya Saing}

Daya saing ekspor merupakan kemampuan suatu komoditas untuk memasuki pasar luar negeri dan bertahan dalam pasar itu. Daya saing ekspor suatu komoditas dapat diukur berdasarkan perbandingan pangsa pasar komoditas tersebut pada kondisi pasar yang tetap (Mahmood, 2000:43). Keunggulan kompetitif dan keunggulan komparatif serta nilai tambah akan sangat menentukan daya saing suatu industri suatu Negara. Porter (1990:218) mengembangkan suatu teori keunggulan kompetitif dengan bertitik tolak dari kenyataan persaingan internasional yang ada, jadi pembentukan teorinya adalah deduktif. Model yang dikembangkan dikenal sebagai Model Berlian.

Penelitian yang dilakukan Meryana (2007) tentang daya saing kopi Robusta Indonesia di pasar kopi Internasional menunjukkan hasil bahwa struktur pasar kopi Robusta di pasar Internasional cenderung ke arah pasar Oligopoli. Negara-negara yang termasuk ke dalam pasar persaingan di tingkat atas yaitu Vietnam, Indonesia, Brazil, Pantai Gading, Uganda, dan India. Hasil ini ditunjukkan melalui skor Herfindahl Index sebesar 0.2 dan nilai Concentration Ratio dari empat produsen kopi Robusta terbesar sejumlah 70 persen. Industri kopi Robusta memiliki keunggulan komparatif dengan nilai Revealed Comparatif Advantage (RCA) yang lebih dari satu. Pada tahun 2006 Indonesia memiliki nilai RCA sebesar 9.70 yang menunjukkan adanya keunggulan komparatif pada komoditas kopi Robusta. Penelitaian Dradjat, Bambang, Adang Agustian dan Ade Supriatna (2007) dengan judul Ekspor dan Daya Saing Kopi Biji Indonesia di Pasar Internasional:Implikasi Strategis bagi Pengembangan Kopi Biji Organik. Tujuan dari penelitian tersebut adalah untuk menganalisis daya saing kopi Indonesia di pasar internasional. Selain itu, penelitian ini juga ditujukan untuk menyampaikan beberapa pandangan tentang kemungkinan pengembangan kopi organik dalam rangka ekspor. Penelitian Hidayat, Ariel dan Soetriono (2010) dengan judul Daya Saing Ekspor Kopi Robusta Indonesia di Pasar Internasional. Penelitian ini menunjukkan bahwa: (1) Indonesia memiliki keunggulan komparatif kopi robusta. (2) Indonesia mampu mencapai pasar kopi robusta selama tahun 2004 sampai 2006. (3) Indonesia memiliki daya saing yang tinggi atau pasokan dalam negeri lebih besar dari permintaan domestik dan Indonesia ditempatkan dalam tahap kedewasaan. (4) Meningkatnya harga kopi robusta dari $5 \%, 10 \%$ dan 20\%, meningkatkan keunggulan komparatif, meningkatkan kegiatan ekspor, dan daya saing kopi robusta adalah konstan. 


\section{METODOLOGI PENELITIAN}

Penelitian ini dilakukan dengan menggunakan data sekunder dari berbagai sumber, di antaranya dari BPS (BPS, 2016), Kementerian Pertanian Indonesia, International Coffe Organization (International Coffee Organization, 2016), dan AEKI (AEKI, 2016). Data sekunder yang digunakan berupa data time series dalam kurun waktu 7 tahun (2010-2016). Kopi yang menjadi objek penelitian adalah semua jenis kopi. Metode analisis data menggunakan metode analisis kuantitatif yang digunakan untuk menganalisis seberapa besar tingkat daya saing ekspor komoditas kopi Indonesia di pasar internasional yang meliputi : Revealed Comparative Advantage (RCA), Import Dependency Ratio (IDR), dan Indeks Spesialisasi Pasar (ISP). Pengolahan data akan dilakukan dengan menggunakan Software Microsoft Excel 2013.

\section{Revealed Comparative Advantage (RCA)}

Indeks RCA merupakan metode yang dikenalkan oleh Bella Balansa. Dasar pemikiran yang melandasi metode ini adalah bahwa kinerja ekspor suatu negara sangat ditentukan tingkat daya saing relatif terhadap produk serupa buatan negara lain dengan asumsi ceteris paribus, yakni bahwa faktor-faktor lain yang mempengaruhi pertumbuhan ekspor tetap. Rumus RCA sebagai berikut:

$$
\begin{aligned}
& R C A=\left(\frac{X_{I K}}{X_{M}}\right) /\left(\frac{X_{W K}}{X_{W M}}\right) \\
& X_{I K}=\text { nilai ekspor produk I negara } \mathrm{K} \\
& X_{M}=\text { total nilai ekspor negara } \mathrm{K} \\
& X_{W K}=\text { nilai ekspor produk I dunia } \\
& X_{W M}=\text { total nilai ekspor dunia }
\end{aligned}
$$

Indeks RCA (lebih dari satu) yang semakin tinggi menunjukkan bahwa negara tersebut memiliki keunggulan komparatif dalam produk tersebut dan berdayasaing kuat, begitu pula sebaliknya. Untuk aspek Intenasional, ekspor kopi Indonesia diasumsikan bersaing dengan Negara besar utama pengekspor kopi yaitu : Brazil (BRA), Vietnam (VNM), Colombia (COL), India (IND).

\section{Import Dependency Ratio (IDR)}

Import Dependency Ratio (IDR) merupakan formula yang menyediakan informasi ketergantungan suatu negara terhadap impor suatu komoditas. Perhitungan IDR tidak termasuk perubahan stok yang dikarenakan besarnya stok, baik dari impor maupun produksi domestik. Adapun formula untuk menghitung IDR adalah sebagai berikut:

$$
I D R=\frac{\text { Impor }}{\text { Produksi }+ \text { Impor - Ekspor }} \times 100
$$

IDR menunjukkan tingkat ketergantungan impor suatu negara atas komoditas tertentu. Semakin besar nilai IDR maka ketergantungan impor negara tersebut terhadap suatu komoditas juga semakin tinggi. Sebaliknya semakin kecil nilai IDR, maka ketergantungan impor suatu negara juga semakin rendah.

\section{Indeks Spesialisasi Perdagangan (ISP)}

Indeks Spesialisasi Perdagangan merupakan suatu metode umum yang sering digunakan sebagai alat ukur tingkat daya saing. Indeks ini digunakan dalam melihat apakah suatu jenis produk di suatu negara cenderung menjadi negara eksportir atau menjadi negara importir. ISP digunakan untuk menganalisis posisi atau tahapan perkembangan suatu komoditas. ISP ini dapat menggambarkan apakah untuk suatu komoditas, posisi Indonesia cenderung menjadi negara eksportir atau importir komoditas pertanian tersebut. Indeks ISP dirumuskan sebagai berikut:

$$
\begin{aligned}
& I S P=\frac{\left(X_{\text {in }}-M_{\text {in }}\right)}{\left(X_{\text {in }}+M_{\text {in }}\right)} \\
& X_{\text {in }}=\text { Nilai ekspor Produk I di suatu negara } \\
& M_{\text {in }}=\text { nilai impor produk I di suatu negara }
\end{aligned}
$$




\section{HASIL DAN PEMBAHASAN}

\section{Analisis tingkat daya saing ekspor kopi Indonesia di pasar Internasional}

Keunggulan komparatif Indonesia dalam pasar kopi dunia diukur dengan menggunakan Indeks Revealed Comparative Advantage (RCA). Indeks ini digunakan untuk membandingkan posisi daya saing Indonesia dengan negara-negara produsen kopi lainnya. Indeks RCA (lebih dari satu) yang semakin tinggi menunjukkan bahwa negara tersebut memiliki keunggulan komparatif dalam produk tersebut dan berdayasaing kuat, begitu pula sebaliknya.

Berdasarkan hasil perhitungan Indeks RCA, semua Indeks RCA Indonesia yang di peroleh memiliki keunggulan komparatif yang ditunjukkan dengan nilai Revealed Comparatif Advantage (RCA) dari tahun 2010-2016 yang lebih dari satu lebih besar dari satu yang menunjukkan bahwa Indonesia sebagai salah satu produsen ekspor kopi memiliki daya saing secara komparatif di pasar dunia, dengan rata-rata RCA sebesar 3.57. Hal ini menunjukkan Indonesia memiliki keuntungan komparatif pada pasar dunia. Pada tahun 2015, Indonesia memiliki nilai RCA tertinggi dibandingkan tahun-tahun lainnya yaitu sebesar 4.28. Hasil ini sesuai dengan penelitian yang dilakukan Hidayat, Ariel dan Soetriono (2010) bahwa Indonesia mempunyai keunggulan komparatif kopi robusta.

Nilai Indeks RCA negara penghasil kopi tahun 2010-2016 dilihat pada tabel 1 berikut:

Tabel 1. Indeks RCA Negara Penghasil Kopi Tahun 2010-2016

\begin{tabular}{|r|l|r|r|r|r|r|r|r|r|}
\hline \multirow{2}{*}{ No. } & Negara & \multicolumn{6}{|c|}{ Tahun } & \multirow{2}{*}{$\begin{array}{c}\text { Rata-Rata } \\
\text { RCA }\end{array}$} \\
\cline { 3 - 9 } & & $\mathbf{2 0 1 0}$ & $\mathbf{2 0 1 1}$ & $\mathbf{2 0 1 2}$ & $\mathbf{2 0 1 3}$ & $\mathbf{2 0 1 4}$ & $\mathbf{2 0 1 5}$ & $\mathbf{2 0 1 6}$ & \multicolumn{3}{|c|}{} \\
\hline 1 & Indonesia & 3.21 & 2.56 & 3.62 & 4.25 & 3.46 & 4.28 & 3.59 & $\mathbf{3 . 5 7}$ \\
\hline 2 & Brazil & 16.41 & 15.75 & 13.01 & 12.55 & 15.74 & 15.66 & 13.50 & $\mathbf{1 4 . 6 6}$ \\
\hline 3 & Vietnam & 15.95 & 14.31 & 17.02 & 12.78 & 12.9 & 8.64 & 12.03 & $\mathbf{1 3 . 3 8}$ \\
\hline 4 & Colombia & 29.91 & 23.44 & 17.85 & 21.61 & 26.89 & 38.83 & 40.92 & $\mathbf{2 8 . 4 9}$ \\
\hline 5 & India & 1.08 & 1.13 & 1.16 & 1.12 & 1.00 & 1.10 & 1.09 & $\mathbf{1 . 1 0}$ \\
\hline
\end{tabular}

Berdasarkan table 1, semua Indeks RCA Indonesia yang di peroleh dari tahun 20102016 adalah lebih besar dari satu yang menunjukkan bahwa Indonesia sebagai salah satu produsen ekspor kopi memiliki daya saing secara komparatif di pasar dunia, dengan rata-rata RCA sebesar 3.57. Namun, nilai RCA dari Vietnam melebihi nilai RCA Indonesia dengan nilai sebesar 13.38, begitu juga dengan nilai RCA dari Brazil mencapai nilai sebesar 14.66. Nilai RCA terbesar adalah Colombia dengan nilai rata-rata RCA sebesar 28.49 sedangkan India mempunyai nilai rata-rata RCA yang paling rendah yaitu sebesar 1.10. Jika dilihat dari tabel 7, indeks RCA yang dimiliki oleh Indonesia masih rendah bila dibandingkan dengan Colombia, Brazil dan Vietnam, namun lebih tinggi dibandingkan India. Hal ini menunjukkan daya saing Indonesia masih rendah jika dibandingkan dengan negara Colombia, Brazil dan Vietnam yang merupakan negara produsen maupun eksportir kopi utama di dunia. Salah satu penyebabnya adalah perbandingan nilai ekspor kopi yang dimiliki oleh Indonesia masih lebih rendah dibandingkan Negara Colombia, Brazil dan Vietnam, namun masih lebih tinggi dibandingkan India.

Tabel 2. Nilai Import Dependency Ratio (IDR) kopi di Indonesia

\begin{tabular}{|c|c|c|c|c|}
\hline Tahun & Produksi kopi (\$USD & $\begin{array}{l}\text { Import kopi } \\
\text { (\$USD) }\end{array}$ & $\begin{array}{l}\text { Export kopi } \\
\text { (\$USD) }\end{array}$ & IDR $(\%)$ \\
\hline 2010 & $4,109,205,920$ & $34,852,000$ & 814,311 & 1.05 \\
\hline 2011 & $6,100,870,023$ & $49,119,000$ & $1,036,671$ & 0.96 \\
\hline 2012 & $5,739,344,694$ & $117,196,000$ & $1,249,519$ & 2.54 \\
\hline
\end{tabular}




\begin{tabular}{|l|l|r|r|r|}
\hline \hline 2013 & $5,536,788,377$ & $38,838,000$ & $1,174,044$ & 0.88 \\
2014 & $5,188,464,292$ & $46,768,000$ & $1,039,609$ & 1.11 \\
2015 & $4,193,250,366$ & $31,492,000$ & $1,197,735$ & 1.04 \\
2016 & $2,996,169,816$ & $48,473,000$ & $1,008,549$ & 2.38 \\
\hline
\end{tabular}

Berdasarkan nilai IDR kopi Indonesia pada tabel 2, terlihat bahwa Rata-rata IDR Indonesia tahun 2010 sampai 2016 sebesar 1.42 yang menunjukkan Indonesia masih memiliki ketergantungan impor kopi dunia. Pada tahun 2010 Indonesia mengalami ketergantungan terhadap impor kopi dunia sebesar 1.05 persen dan meningkat tajam pada tahun 2012 yaitu sebesar 2.54 persen. Hal tersebut diakibatkan oleh jumlah produksi kopi yang menurun tajam, yaitu dari 6,100,870,023 \$USD pada tahun 2011 menjadi 5,739,344,694 \$USD pada tahun 2012 sehingga terjadi kekurangan jumlah produksi kopi domestik yang mengakibatkan terjadinya peningkatan import untuk memenuhi kebutuhan konsumsi domestik. Tingkat ketergantungan impor kopi di Indonesia tertinggi terjadi pada tahun 2012, yang disebabkan oleh adanya peningkatan jumlah impor kopi, yaitu sebesar 49,119,000 \$USD di tahun 2011 menjadi 117,196,000 \$USD di tahun 2012. Hal ini menunjukkan adanya tingkat ketergantungan impor kopi di Indonesia yang semakin meningkat.

Tabel 3. Nilai Indeks Spesialisasi Perdagangan (ISP) Kopi di Indonesia

\begin{tabular}{|r|r|r|r|}
\hline Tahun & Import kopi & $\begin{array}{l}\text { Export kopi } \\
\text { (\$USD) }\end{array}$ & \multicolumn{1}{|l|}{ ISP } \\
\hline 2010 & $34,852,000.00$ & $814,311,000.00$ & 0.92 \\
2011 & $49,119,000.00$ & $1,036,671,000.00$ & 0.91 \\
2012 & $117,196,000.00$ & $1,249,519,000.00$ & 0.83 \\
2013 & $38,838,000.00$ & $1,174,044,000.00$ & 0.94 \\
2014 & $46,768,000.00$ & $1,039,609,000.00$ & 0.91 \\
2015 & $31,492,000.00$ & $1,197,735,000.00$ & 0.95 \\
2016 & $48,473,000.00$ & $1,008,549,000.00$ & 0.91 \\
\hline & & Rata-rata ISP = & $\mathbf{0 . 9 1}$ \\
\hline
\end{tabular}

Berdasarkan hasil perhitungan ISP Indonesia pada tabel 3, menunjukkan bahwa Indonesia merupakan negara eksportir kopi yang dilihat dari nilai rata-rata ISP sebesar 0.91 menunjukkan bahwa komoditi kopi Indonesia tersebut mempunyai daya saing kuat karena mempunyai nilai positif diatas 0 dan hampir mendekati 1, sehingga negara Indonesia cenderung sebagai pengekspor dari komoditi kopi.

\section{PENUTUP}

KESIMPULAN : (1) Berdasarkan hasil analisis nilai RCA, Indonesia memiliki keunggulan komparatif dalam perdagangan kopi di pasar internasional dengan rata-rata nilai RCA Indonesia dari tahun 2010-2016 sebesar 3.57. Namun Keunggulan komparatif yang dimiliki oleh Indonesia masih rendah dibandingkan dengan negara Colombia, Vietnam dan Brazil, meskipun masih lebih tinggi dibandingkan India. (2) Tingkat ketergantungan impor kopi Indonesia yang dihitung dengan menggunakan Import Dependency Ratio (IDR) pada kurun waktu tahun 2010-2016 rata-rata sebesar 1.42 persen. Hal ini menunjukkan adanya tingkat ketergantungan impor kopi Indonesia sebesar 1.42 persen. Masih adanya tingkat ketergantungan import kopi Indonesia tersebut, akan mengakibatkan kebutuhan impor kopi semakin meningkat setiap tahunnya sehingga kopi domestik akan semakin terancam. (3) Kopi Indonesia memiliki daya saing yang tinggi, karena nilai Indeks Spesialisasi Perdagangan (ISP) kopi Indonesia sebesar 0.91. Hal ini menandakan bahwa Indonesia merupakan negara pengekspor untuk komoditas kopi. Hasil ISP yang positif lebih besar 
dari 0 menunjukkan bahwa komoditi kopi Indonesia tersebut mempunyai daya saing kuat, karena nilai ekspor kopi Indonesia lebih besar dari nilai import kopi Indonesia.

SARAN Terkait dengan hasil penelitian ini, terdapat beberapa saran yang dapat diberikan sebagai berikut : (1) Meningkatkan keunggulan kompetitif kopi Indonesia di pasar Internasional melalui perbaikan teknik budidaya, penyediaan modal, dan pengadaan infrastruktur yang mendukung terhadap industri kopi Indonesia sehingga dapat menghasilkan kopi yang berkualitas dan mampu bersaing dengan negara-negara produsen kopi di dunia. Perhatian ini bisa berupa kebijakan tentang kemudahan dalam sarana dan prasarana produksi kopi, pengadaan pupuk dan obat, pengadaan bibit unggul maupun dalam bentuk penyuluhan pertanian yang lebih intensif khususnya di sentra-sentra produksi kopi. (2) Peran pemerintah juga sangat diharapkan, yaitu dengan melakukan penetapan tarif impor kopi yang tepat untuk melindungi kopi domestik serta melakukan pembatasan volume impor kopi yang masuk ke Indonesia untuk menjaga kestabilan harga sekaligus menjamin kelangsungan hidup industri kopi nasional dan petani kopi sebagai produsen kopi. (3) Pemerintah harus memperhatikan potensi besar dari kopi Indonesia mengingat peranannya yang cukup besar dalam perekonomian. Perhatian ini bisa berupa kebijakan tentang kemudahan dalam sarana dan prasarana produksi, pengadaan pupuk dan obat, pengadaan bibit unggul maupun dalam bentuk penyuluhan pertanian yang lebih intensif khususnya di sentra-sentra produksi kopi.

\section{DAFTAR PUSTAKA}

Badan Pusat Statistik. 2016, Ekspor Kopi Menurut Negara Tujuan Utama, 2008-2014, Retrieved March 22, 2018, from www.bps.go.id

Case, E., Karl and Fair, C., Ray. 2007. Prinsip-Prinsip Ekonomi. Jakarta: Penerbit Erlangga

Idris, Muhammad, 2017, Kopi RI Dicari Pasar Dunia, Tapi Produksinya Kurang, Retrieved March 22, 2018, from https://finance.detik.com/berita-ekonomi-bisnis/d3497150/kopi-ri-dicari-pasar-dunia-tapi-produksinya-kurang

Hady, H. 2001. Ekonomi Internasional. Bogor: Ghalia Indonesia

Kementrian Perdagangan. 2014. Produksi Kopi Nusantara Ketiga Terbesar di Dunia. Jakarta

Krugman, P. R. dan M. Obstfeld. 1990. International Economics Theory and Policy. New York: Harper Collins Publishers

Mahmood, A. 2000. Trade Liberalization and Malaysian Export Competitiveness: Prospects, Problems, and Policy Implications. Departemen of Economics, University of Newcastle, Australia

Meryana, E. 2007. Analisis Dayasaing Kopi Robusta Indonesia di Pasar Internasional. Skripsi. Program Sarjana Manajemen Agribisnis, Fakultas Pertanian, Institut Pertanian Bogor. Bogor.

Porter, Michael E. 1990. The Competitive Advantage of Nations. New York: The Free Press.

Prasetyo, P. E. 2011. Fundamental Makro Ekonomi. Yogyakarta: Beta Offset

Tambunan, Tulus. 2004. Globalisasi dan Perdagangan Internasional. Jakarta: Ghalia Indonesia.

Utomo, Yuni Priadi. 2000. Ekspor Mendorong Pertumbuhan atau Pertumbuhan Mendorong Ekspor, Jurnal Manajemen, Vol.1, No.1, UII. Yogyakarta.

Sujuna Ismaya, dan Sigit Wiharno, 2003, Kamus Besar Ekonomi, Bandung : CV Pustaka Grafika,

Sukirno, Sadono. 2008. Mikro Ekonomi Teori Pengantar. Jakarta. P.T Raja Grafindo Persada

Data Sekunder:

AEKI. 2016. Perkembangan Pasar Kopi Indonesia. Jakarta

Badan Pusat Statistik. 2016. Ekspor Kopi Menurut Negara Tujuan Utama, 2008-2014 (www.bps.go.id). [29 November 2017] 
Devito Martha, 2017, Kopi local sebagai Peluang Baik Bagi Startup Kopi di Indonesia, Retrieved March 22, 2018, from (https://www.kompasiana.com/ devitomartha/ kopilokal-sebagai-peluang-baik-bagi-startup-di-Indonesia_588622e05293730 9188b5b6e

Elisabeth Adventa, 2017, Permintaan kopi naik, produksi justru turun, Retrieved Nov 22, November 2018, from https://industri.kontan.co.id/news/permintaan-kopi-naikproduksi-justru-turun

Finance.detik.com, 2014, Produksi Kopi RI Turun Tiap Tahun, Ini Penyebabnya, Retrieved March 22, 2018, from http://www.kemendag.go.id/id/economic-profile/10-main-andpotential-commodities.

International Coffee Organization. 2016. The Current State of the Global Coffee Trade (http://www.ico.org/ monthly_coffee_trade_stats.asp). [29 November 2017

Kementrian Perdagangan. 2014. Produksi Kopi Nusantara Ketiga Terbesar di Dunia. Jakarta

Sadakoffie.com , 2018, Kopi Wajib memiliki Standar Mutu sebagai control kualitas cita rasa, Retrieved March 22, 2018, from https://www.sadakoffie.com/kopi-wajibmemiliki-standar-mutu-sebagai-control-kualitas-cita-rasa 


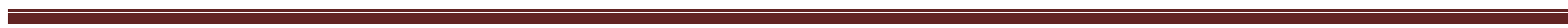
$\cdot$ 